Volume 62

Issue 2 Winter 2013: Symposium - A

Celebration of the Thought of Marc Galanter

Article 7

\title{
When Institutions Fail: The Case of Underage Marriage in India
}

Michele Goodwin

Follow this and additional works at: https://via.library.depaul.edu/law-review

\section{Recommended Citation}

Michele Goodwin, When Institutions Fail: The Case of Underage Marriage in India, 62 DePaul L. Rev. 357 (2013)

Available at: https://via.library.depaul.edu/law-review/vol62/iss2/7

This Article is brought to you for free and open access by the College of Law at Digital Commons@DePaul. It has been accepted for inclusion in DePaul Law Review by an authorized editor of Digital Commons@DePaul. For more information, please contact digitalservices@depaul.edu. 


\title{
WHEN INSTITUTIONS FAIL: THE CASE OF UNDERAGE MARRIAGE IN INDIA
}

\author{
Michele Goodwin*
}

\section{INTRODUCTION}

When do we know that the rule of law has failed or been corrupted? Who can we point to as corrupting legal order or the rule of law when most litigating parties appear to be "one-shotters"? In his seminal work, Why the "Haves" Come Out Ahead: Speculations on the Limits of Legal Change, Professor Marc Galanter points to "one-shotters" as the vulnerable, unable to quickly master, and more importantly conquer, sophisticated legal labyrinths made less an enigma to "repeat players"- the legal elites. ${ }^{1}$ In India, the lines that divide the elite from the less sophisticated, or the repeat players from the one-shotters, are as thick as the social customs that once divided the nation into castes. However, the lines separating individual one-shotters may be more ambiguous and less distinct, as even Galanter acknowledged.

In India, as in the Western world, the subject of women's rights has been deeply contested over time. To be sure, the law functions as a

* President, Defense for Children International (USA); Everett Fraser Professor of Law, University of Minnesota Law School; Professor of Medicine \& Public Health, University of Minnesota. This project brings several research conversations together in a harmony, inspired by the works of Marc Galanter and facilitated by the extraordinary talent of Stephan Landsman in orchestrating a dynamic symposium on important sociolegal questions. My thanks to both gentlemen, along with Robert Clifford, for providing me an opportunity to join in conversation with others to honor Marc. I also wish to thank the Robina Foundation for providing the financial support to engage in the demanding, on-the-ground research from which this project developed and continues to grow. This project continues to benefit from the insight of insiders - two of whom deserve mention and my gratitude are Francis Kessling and Shyamala Rajender, remarkable women in their own right. I am also indebted to Hari Prasad Churasia, Rajas Kasbekar, Dora Giusti, Mini Rajkumar, and Debolina Dutta. This project owes much to Jose Bergua, Chief of Child Protection for United Nations Children's Fund's (UNICEF) office in India, whose expertise, research, contacts, and thoughtful interactions benefited this project. Finally, my thanks to a few organizations: Creating Resources for Empowerment in Action (CREA), SAKHI Women's Resource Center in Kerala, and UNICEF, as their insider perspectives and data about local and national politics of child marriage, child sex, and the life of women in India were invaluable. I also wish to express my gratitude to outstanding students who assisted with this project: Allison Whelan, my research assistant, and the editors of the DePaul Law Review. The individuals and organizations acknowledged here bear no responsibility for the views set forth in this Article.

1. Marc Galanter, Why the "Haves" Come Out Ahead: Speculations on the Limits of Legal Change, 9 Law \& Soc'y REv. 95, 97 (1974). 
vehicle to uplift women, erecting rights where previously none existed, including granting the right to vote,$^{2}$ creating entitlements to fair wages, ${ }^{3}$ establishing just labor practices, ${ }^{4}$ and accommodating family planning in the work place, ${ }^{5}$ to name a few. Historically, however, law has also been used as a tool to undercut the basic human rights of women and diminish their status in society. Examples of the legal subordination of women abound throughout both the West and the East. Social and political mechanisms like coverture, which was borrowed from French law and adopted in English and early American common law, provide a potent example. ${ }^{6}$ Coverture rules denied property rights to married women and established them as property owned by their husbands and fathers. ${ }^{7}$ This complicated legacy cannot be denied, even as we mark significant progress on the rights and advancements of women who are aided by the rule of law.

In other words, gender oppression can, and too frequently does, exist alongside gender equality. Social status, class, and tribal affiliation affect the lives and opportunities of women differently in any given society. The experiences of elites in society, for example, whether men or women, can and will differ vastly from those whose lives are consumed by poverty, poor healthcare, and hunger. One cannot be naive to these realities; in fact, for the rule of law to be a meaningful tool, its reach must extend beyond the elite-those who are educated, privileged, and politically leveraged.

It is with this in mind that this Article evaluates the usefulness, promise, and impact of the rule of law on young women in India. Indeed, the rule of law has come under attack by scholars who have suggested that it is overly optimistic, if not misleading, as a tool for achieving gender equality. ${ }^{8}$ The complaint is that the rule of law can

2. U.S. Const. amend. XIX.

3. 29 U.S.C. $\& 206(d)(2006)$.

4. See, e.g., National Labor Relations Act, 29 U.S.C. $\S \S 151-69$ (2006) (providing workers, both male and female, a variety of rights, such as forming labor unions, engaging in collective bargaining, and going on strike).

5. See 29 U.S.C. $\$ 2601$ (2006) (stating that one purpose of the Family and Medical Leave Act of 1993 is "to balance the demands of the workplace with the needs of families").

6. See Claudia Zaher, When a Woman's Marital Status Determined Her Legal Status: A Research Guide on the Common Law Doctrine of Coverture, 94 Law LiBr. J. 459 (2002) (providing an overview and compilation of a variety of sources discussing the history and current status of the common law coverture doctrine).

7. See id. at 459-60 (quoting 1 William Blackstone, Commentaries *442) (noting that, under the doctrine of coverture, the "legal existence of the woman is suspended during the marriage").

8. See, e.g., Moni Pizani, Foreword to UnITEd Nations EnTtTy for Gender Eouality and the Empowerment of Women, Do Our Laws Promote Gender Equality?, at i (3d ed. 2012), available at http://cedaw-seasia.org/docs/FINAL_CEDAW_Handbook.pdf ("Many Gov- 
mask inequality in society. ${ }^{9}$ Socio-legal scholars remind us that the law as written is meaningless if not enforced. ${ }^{10}$ Granting women the right to vote while prohibiting or limiting access to voting is a provocative example of institutional failure and illustrates how the law must live beyond legislation or text.

This Article casts a narrow net, examining institutional failure in the protection of children. Specifically, the research project from which this Article developed studied the prevalence of young women forced or trafficked into domestic partnerships in India, South Africa, and the Philippines. Each country has a well-known, distinct treatment of child brides both within the law and their individual societies. ${ }^{11}$ This Article narrows that grouping even further and examines the ways in which young women's life choices and capacities become diminished through arranged marriages in India, which often contravene local legislation, but are not usually overturned by local courts after nuptials are final. Indeed, judges engage in marital ceremonies as key players or collaborators in law's failure-they often perform the nuptials. Advocacy organizations estimate that the cases capturing international attention, such as ten-year-old girls successfully winning divorces against older husbands, represent only a fraction of forced child marriages. ${ }^{12}$

Despite the enactment of laws prohibiting underage matrimony in India, an incredibly high incidence of child marriage persists, exposing the law's weakness or failure. In India, for example, $43 \%$ of all girls are forced into marriage before the age of eighteen, ${ }^{13}$ which is the

ernments believe that gender-neutral laws benefit women and men equally, while in fact-due to deeply rooted structural, institutional, social, and cultural barriers for women-the opposite is often true. Failure to consider and address gender differences in laws perpetuates gender inequality.") (emphasis added).

9. See Catherine R. Albiston, Institutional Inequality and the Mobilization of the Family and Medical Leave ACt 13 (2010) ("[R]elying on rights may merely reinforce and legitimize a legal system that masks inequality." (citation omitted)).

10. See, e.g., Orly Lobel, The Paradox of Extralegal Activism: Critical Legal Consciousness and Transformative Politics, 120 Harv. L. REv. 937, 954 (2007) ("Judgments are handed down, but they frequently are not in fact enforced. Litigation thus will not produce lasting social consequences for those who choose the legal path.").

11. The Girls Not Brides partnership monitors child marriages internationally, including within the countries studied through my project. See Where Does It Happen?, GirLs Not Brides: The Global Partnership to End Child Marriage, http:/www.girlsnotbrides.org/ where-does-it-happen (last visited Feb. 7, 2013). The organization confirms the global reach of child marriages and the many ways in which girls are harmed by these arrangements. See id.

12. See generally Nujood Ali with Delphine Minoui, I Am Nujood, Age 10 and DivORCED (Linda Coverdale trans., 2010) (detailing the story of Nujood Ali, a ten-year-old girl from Yemen who successfully divorced her husband in April 2008).

13. UNICEF Information Sheet: Child Marriage, UNICEF 1 (2011), http:/www.unicef.org/india/Child_Marriage_Fact_Sheet_Nov2011_final.pdf [hereinafter Child Marriage]. 
legal age of marriage. ${ }^{14}$ In one northern state, the rate of women forced into underage marriage is almost $70 \% .^{15}$ These marriages extend deeply rooted cultural norms that represent more than the symbolic joining of households; they perpetuate and further entrench a complex system of gender subordination that includes intra-gender slavery and abuse, ${ }^{16}$ denial of education, ${ }^{17}$ domestic violence, ${ }^{18}$ marital rape, ${ }^{19}$ teenage pregnancy, ${ }^{20}$ maternal and child mortality, ${ }^{21}$ the transmission of sexually transmitted diseases (including HIV and AIDS), ${ }^{22}$ and dowry (another illegal practice that persists in the shadows of law).23

In India, child-bride trafficking often operates under the trained radars of human rights organizations, both within and outside the country. For example, organizations that tend to advocate against domestic violence toward women often view women and not girls as the beneficiaries of their advocacy. Thus, girls forced into underage marriages occupy a distinct cohort that too often slips through the cracks of advocacy organizations and the legal regimes of Western countries interested in providing political guidance and aid to developing nations. ${ }^{24}$

When the U.S. Department of State attacks international trafficking, it does so with a different "victim" cohort in mind. ${ }^{25}$ The federal

14. Id. at 3 .

15. Data from 2007 to 2008 illustrate that $68.2 \%$ of women between the age of twenty and twenty-four in Bihar were married before the age of eighteen. Id. at 1.

16. $I d$. at $1-2$.

17. $I d$.

18. Id. at 1 .

19. Cf. Child Marriage, supra note 13, at 1-2 (noting that young girls lack the "negotiation skills and experience" that would allow them greater control over their sexual relations).

20. See id. at 1 .

21. $I d$.

22. $I d$.

23. $I d$. at 2 .

24. See, e.g., Maggie Bangser, USAID, 'Falling Through the Cracks'-Adolescent Girls IN TANZANIA: INSIGHTS FROM MTwARA 3 (2010), available at http://www.svri.org/adol.pdf ("[G]irls continue to 'fall through the cracks' of most development policies and programs worldwide.").

25. In a recent speech at Dublin City University, then-Secretary of State Hillary Rodham Clinton offered a promising turn in U.S. Department of State policy, pledging that the United States will begin monitoring underage marriages in developing nations, beginning in 2013. See Hillary Rodham Clinton, Secretáry of State, U.S. Dep't State, Frontlines and Frontiers: Making Human Rights a Human Reality (Dec. 6, 2012) (transcript available at http://www.state.gov/secretary/rm/2012/12/201618.htm). The potential scope of U.S. efforts in this domain remains unarticulated and may depend upon who succeeds Secretary Clinton as the U.S. Secretary of State. In the meantime, data collection and monitoring may help to convince U.S. lawmakers that underage marriage impacts the lives of girls in developing nations and pressure nations to report the practice. However, eradicating child marriage will demand more. In fact, collecting data is 
approach has been to group all "sex work" into sex trafficking while leaving out underage marriage-the first step in sex work for many underage brides. ${ }^{26}$

According to the Tahirih Justice Center, a prominent legal defense organization, "the United States . . . lags far behind-and until now, has done little to recognize or address the problem of forced marriage. Domestically, there are very few laws and policies specifically to help forced marriage victims, leaving young women (and some men) in crisis with few resources and options." 27 These tensions are further complicated by the West's post-colonial, "hands-off" approach to challenging custom or traditional norms in developing nations, selectively aiding and intervening among nations during conflict. ${ }^{28}$

In fact, uncertainty persists among domestic law enforcement as to when and how to intervene when sexually violent practices emigrate along with their victims into the United States. ${ }^{29}$ In 2011, the Tahirih Justice Center conducted a national survey of more than 500 legal, medical, social service, educational, and religious agencies, which found that $67 \%$ of survey respondents believe cases of forced marriage occur among the populations they serve in the United States. ${ }^{30}$ The immigrant victims, however, remain significantly underserved, as only $16 \%$ of respondent agencies claimed to be equipped to help the victims they encounter. ${ }^{31}$

Chris Boughey, the lead officer who investigated the death of Noor Almaleki (a young woman murdered by her father for becoming "too westernized") explained to reporters, "We don't have the mechanisms

not the challenge; enforcing states' laws that penalize the practice is the more challenging problem.

26. See 18 U.S.C. $\S 1591$ (2006 \& Supp. IV 2011). From a practical standpoint, it would be difficult to prosecute a person for the sex trafficking of a spouse. See id.

27. Tahirih Justice Center, Forced Marriage in Immigrant Communities in the United States: 2011 National Survey Results 1 (2011), available at http:/www.tahirih.org/ site/wp-content/uploads/2011/09/REPORT-Tahirih-Survey-on-Forced-Marriage-in-ImmigrantCommunities-in-the-United-States-September-20114.pdf.

28. See Linda Burstyn, Female Circumcision Comes to America, Atlantic Monthly, Oct. 1995 , at 28.

29. Underage marriage occurs as "tradition" in many developing countries, including India. In some countries the practice is confined to discrete ethnic minorities, while in others, the practice extends beyond tribal affiliations and ethnic divides. The United States and other Western nations choose not to leverage sanctions against India even though underage marriages occur with some frequency, often involving sexual violation and rape, as well as elements of trafficking. This Article does not make a policy argument about that strategy (the use of sanctions) to reduce the incidences of child marriage. The point here is that "tradition" can be strategically leveraged to maintain draconian practices in developing nations, even while economic and political partnerships are formed with the West that urge social transformation. See id.

30. See TAhirih Justice Center, supra note 27, at 4-5.

31. Id. at 3. 
in place here in the U.S. to take care of these girls."32 Boughey, who serves as an investigator at Arizona's Peoria Police Department, laments his department's limitations: "What do we do with a teenager runaway? Ninety-nine percent of the time, we take her home. But some of these [immigrant] girls end up getting killed." 33 Advocacy organizations notice the law enforcement gaps:

When Tahirih began to work on these cases, we were struck by how few resources and legal options exist in the United States to assist individuals facing forced marriages, as well as how little awareness or understanding there is nationwide about the unique dynamics and challenges in forced marriage situations. ${ }^{34}$

Suffering, then, are girls.

Linda Burstyn underscores this point in a particularly chilling account of female genital mutilation and Western passivity, chronicled in the Atlantic Monthly. ${ }^{35}$ She noted:

Even though the details of some of the extreme yet common forms of the practice are as horrifying to most Americans as Nazi human experimentation or brutal child abuse, documentation is hard to come by, and resistance to infringing upon the traditions and mores of another culture is difficult to overcome. ${ }^{36}$

Catherine Hogan, founder of the Washington Metropolitan Alliance Against Ritualistic FGM, framed the issue along the lines of race:

When you wrap this issue in the cloth of culture, you just can't see what's inside. This is a clear case of child abuse. It's a form of reverse racism not to protect these girls from barbarous practices that rob them for a lifetime of their God-given right to an intact body. ${ }^{37}$

Jeffrey Reitz, a professor at the University of Toronto, concurs, noting that when the matter involves domestic violence and even murder, "[i]f you label it an honor killing, the tendency is to say, 'Oh, what a terrible culture that is,' and the problem (of domestic violence) stems across cultural groups." 38

Forced underage marriages pose significant public health problems, in addition to human rights and criminal law complications. In India, judges informed me that they attempt to mitigate harms associated

32. Julia Dahl, "Honor Killing" Under Growing Scrutiny in the U.S., CBS NEwS: CRIMESIDER (Apr. 4, 2012, 3:40 PM), http://www.cbsnews.com/8301-504083_162-57409395-504083/honor-killing-under-growing-scrutiny-in-the-u.s.

33. Id.

34. See TAhirih Justice Center, supra note 27, at 2.

35. See Burstyn, supra note 28.

36. Id.

37. ld. (internal quotation marks omitted).

38. Christopher Santarelli, Honor Killings Prompt Debate in Canada on Assimilating Immigrants, BLAZE (Dec. 25, 2011, 5:15 PM), http:/www.theblaze.com/stories/2011/12/25/honor-killings-prompt-debate-in-canada-on-assimilating-immigrants (internal quotation marks omitted). 
with forced marriage by encouraging girls to apply for divorce after reaching the age of puberty. Rather than incentivizing young women to come forward, however, such posturing from the bench may serve as a disincentive. The likelihood (and safety) of girls escaping difficult domestic living arrangements to petition courts for divorce after several years of marriage, possibly with children, is doubtful. What connects these stories are the ways in which courts often fail to address the underlying legal and social reality: young girls are bartered and sold into marriages, frequently in violation of the law and international treaties.

In Why the "Haves" Come Out Ahead, Marc Galanter observed, "Most analyses of the legal system start at the rules end and work down through institutional facilities to see what effect the rules have on the parties."39 Like Galanter's seminal article, this project reorders that hierarchy and considers the entrenched problem of child marriage from the ground up. In other words, this project invites a reflection on law's order by visiting the players and studying how their statuses function to inscribe "the way the system works." 40 India's underage-marriage markets reveal the autonomous, complex, and duplicitous roles of government. On the one hand, rule development is shaped by exogenous forces and demands. Government officials, however, too frequently perceive law or legislation as "enough." 41 That is, they perceive rule development as initiating, concluding, and satisfying socio-legal obligations.

On the other hand, courts function with significant independence and autonomy, habitually deferring as much to the "laws" of custom, as they do legislative law or judicial common law. ${ }^{42}$ Often, especially in matters of civil or human rights, the law of custom conflicts with newly developed legislative principles and rules. ${ }^{43}$ This is particularly the case in underage marriage, but the theory could be applied to other matters of family law including infanticide, sex selection, domestic violence, and marital rape. ${ }^{44} \mathrm{I}$ have chosen underage marriage be-

39. Galanter, supra note 1 , at 97.

40. Id.

41. See, Albiston, supra note 9, at 13; Lobel, supra note 10, at 954; Pizani, supra note 8, at i.

42. Interview with Pancham Lal, Sec'y to Parliament Affairs, State of Bihar, in Bihar, India (Feb. 18, 2011).

43. See Int'l Planned Parenthood Fed'n, Ending Child Marriage: A Guide for GLOBAL Policy ACtion 2 (2006), available at http://www.unfpa.org/upload/lib_pub_file/662_file name_endchildmarriage.pdf ("Most countries have laws on the minimum age of marriage, but they are largely ineffective, not enforced or operate alongside customary and religious laws.").

44. Untted Nations, 15 Years of the United Nations Spectal Rapporteur on Violence Against Women, Its Causes and Consequences 4-5 (2009), available at http://www. 
cause it is a particularly potent example of courts' deference to traditional norms and values. ${ }^{45}$

Who benefits, then, from the courts' adherence to custom over legislative law? Repeat players, such as marriage brokers ${ }^{46}$ and polygamists, and one-shotters-groomsmen intending to marry underage girls and families committed to forcing their daughters into marriages-benefit from judicial flexibility or passivity. Thus, whether repeat players or one-shotters, "tradition" can maximize opportunities to influence judicial decision making, in addition to undermining oneshotters who appeal to the rule of law.

Clearly then, not all repeat players fit the traditional definition of "haves," nor can all one-shotters be categorized as "have-nots," as defined by Galanter's iconic work. ${ }^{47}$ Indeed, rural poverty may, at first glimpse, rule Galanter's framework inapplicable; poverty pervades northern, rural Indian states. Local law is often tribal law, enforced by village chiefs. Wealth in some of these communities can be defined by owning a single cow or goat; every resource is used, including dung to create patties for which women use as fuel for heating and cooking. Children, cows, and other animals bathe and drink from the same water; everyone is malnourished-the children, animals, and their mothers. In this space of abject poverty, one could easily conclude that no "haves" exist. Status, however, may be difficult to discern with Western eyes, which view all small, crowded huts with bare, dirt floors as indistinguishable from one another.

On close inspection, however, the defining features that distinguish the "haves". from the "have-nots" tumble to the fore. Power matters throughout India, and large rural states are no exception. Power, status, and the means to regenerate and to create wealth are determined by gender. ${ }^{48}$ Thus, sex also matters. ${ }^{49}$ In other words, that which is

ohchr.org/Documents/Issues/Women/15YearReviewofVAWMandate.pdf (discussing custom's role in enforcing various forms of violence against women and girls).

45. See Interview with Pancham Lal, supra note 42.

46. India's marriage market drives a significant portion of the economy at 250 billion Indian rupies per year. The business is lucrative and an evolving part of the economic and social fabric of the nation. See Ira Trivedi, The (New) Business of Marriage, Hindustan Times (Oct. 28, 2011), http:/www.hindustantimes.com/Entertainment/Luxury/The-new-business-of-marriage/Article1-762156.aspx.

47. See Galanter, supra note 1 , at 97-98.

48. " 'Gender' refers to the socially constructed roles, behaviours, activities, and attributes that a given society considers appropriate for men and women." See What Do We Mean by "Sex" and "Gender"?, World Health ORG., http://www.who.int/gender/whatisgender/en (last visited Feb. 7, 2013).

49. "'Sex' refers to the biological and physiological characteristics that define men and women." Id. 
true in most of India-men matter-is amplified in rural communities. A premium is placed on male births and, to an equal degree, punishment and disdain accompanies the births of girls. ${ }^{50}$ To explain further, birthing sons (and manhood itself) inculcates a higher order status or privilege, which carries weight not only in the home, but also within the judicial system in local courts.

Thus, even within a deeply entrenched society of male dominance, power, and control, the status of women varies in rural communities; some women are "haves" in rural villages and wield their power with brutal force against their "have-not" daughters-in-law. Because fluidity exists within these categories, the ways in which intrafamilial arrangements and relationships of competing parties (mothers-in-law versus daughters-in-law, grooms versus brides, brides versus their parents, and all parties versus marriage brokers) clearly indicate what advantages are thereby reinforced and augmented. According to Galanter, "This position of advantage is one of the ways in which a legal system formally neutral as between 'haves' and 'have-nots' may perpetuate and augment the advantages of the former." 51

This Article takes up the case of child marriage in India to demonstrate why the "haves" come out ahead in India's marriage markets. To do so, it exposes the descriptive gaps that lead to normative challenges in the implementation and enforcement of India's marriage laws: the Hindu Marriage $\mathrm{Act}^{52}$ and the Prohibition of Child Marriage Act. ${ }^{53}$ As a descriptive matter, India's marriage law system, governed primarily by the Hindu Marriage Act, ${ }^{54}$ is replete with competing laws, including the Muslim Marriage Act, ${ }^{55}$ the Indian Christian Marriage Act, ${ }^{56}$ the Parsi Marriage and Divorce Act, ${ }^{57}$ the Special Marriage Act, ${ }^{58}$ and the Foreign Marriage Act. ${ }^{59}$ Further yet, new marriage acts are frequently proposed to disentangle the overlapping

50. See O.P. Sharma \& Carl Haub, Sex Ratio at Birth Begins to Improve in India, PoPUlation ReFERENCE Bureau (Aug. 2008), http://www.prb.org/Articles/2008/indiasexratio.aspx?p=1,\&p $=1$.

51. Galanter, supra note 1 , at 103-04.

52. This Article refers to the controlling law, the Hindu Marriage Act, which prohibits underage marriage, establishing eligibility at twenty-one for males and eighteen for females. See The Hindu Marriage Act, 1955, No. 25, Acts of Parliament, 1955 (India), amended by The Prohibition of Child Marriage Act, 2006, No. 6, Acts of Parliament, 2007 (India).

53. See The Prohibition of Child Marriage Act, 2006, No. 6, Acts of Parliament, 2007 (India).

54. The Hindu Marriage Act, 1955, No. 25, Acts of Parliament, 1955 (India).

55. Muslim Marriage Act, 1957, No. 53, Acts of Parliament, 1957 (India).

56. Indian Christian Marriage Act, 1872, No. 15, Acts of Parliament, 1872.

57. Parsi Marriage and Divorce Act, 1936, No. 3, Acts of Parliament, 1936 (India).

58. The Special Marriage Act, 1954, No. 43, Acts of Parliament, 1954 (India).

59. Foreign Marriage Act, 1969, No. 33, Acts of Parliament, 1969 (India). 
layers of conflict and inconsistency between the various laws. For example, in 2008, the Law Commission of India proposed the "Laws of Civil Marriages in India-A Proposal to Resolve Certain Conflicts," noting that

[f]or the Hindus, Buddhists, Jainas and Sikhs marrying within these four communities the Special Marriage Act, 1954 is an alternative to the Hindu Marriage Act. The Muslims too have choice between their uncodified personal law and the Special Marriage Act, 1954. But the issue of availability of the Special Marriage Act, 1954 for a marriage, both parties to which are Christians, remains unresolved.60

In other words, there is no unifying law pertaining to religious marriages in India. ${ }^{61}$ Some marriages in India require marriage licenses, while others do not; some marriage laws permit unions between cousins and others do not. ${ }^{62}$ Some traditional norms govern, seemingly trumping federal law, and some traditional norms are now ensconced in law and conflict with federal law, particularly as they relate to marriage. ${ }^{63}$ These descriptive gaps raise questions about federalism and the use of local or state actors-from community chiefs, clergy, matchmakers, and marriage brokers to judges - to interpret and implement federal law.

As a normative matter, implementing "marriage law" in India presents problems and questions for the federal government. These questions range from the basic (How are local authorities to be kept accountable? Should local authorities have less discretion?), to the more nuanced (How should cooperation and collaboration be achieved? What should be done when religion and federal law collide? Do the multiple marriage laws imply that India's Congress assents to the idea that child marriage should also be mutually governed by federal as well as religious law?).

Parts II and III of this Article provide a conspectus, framing the descriptive and empirical components of the project. Part II briefly orients my two years of intermittent field research in India by detailing its scope, approach, and methodology. Part III then turns to the scope of India's child marriage problem. Part IV uses India's mar-

60. Law Comm'n of India, Gov't of India, Laws of Civil Marriages in India-A Proposal to Resolve CeRTAin CONflicts 6 (2008), available at http://lawcommissionofindia.nic. in/reports/report212.pdf.

61. Id. at 14 (proposing that all inter-religious marriages be conducted only under the Special Marriage Act).

62. Id. at 17-20; see also Marriage Procedures in India for NRI's, PIO's or Foreigners, MADAAN \& Co., http://www.madaan.com/marriage.html (last visited Feb. 7, 2013).

63. See Law Comm'n of India, supra note 60 . 
riage law to explore normative questions. Part $\mathrm{V}$ explains why the impact of institutional arrangements perverts the delivery of justice to girls forced into underage marriage. It demonstrates that providing girls with more law does not reduce inequality or create the pathways for equal opportunity or status enhancement. Part VI provides a conclusion.

\section{Background, Scope, and Function of This Research}

This project began as an expanded inquiry into sex trafficking. Most notably, marriage is often removed from the descriptive and theoretical accounts of human and sex trafficking, despite substantial evidence that financial exchanges pervade the formation of modern marriages in many countries, including India. Upon inspection, a probing analysis has not been offered for this gap.

\section{Figure 1: Sixteen-Year-Old Bride and Men of the Village ${ }^{64}$}

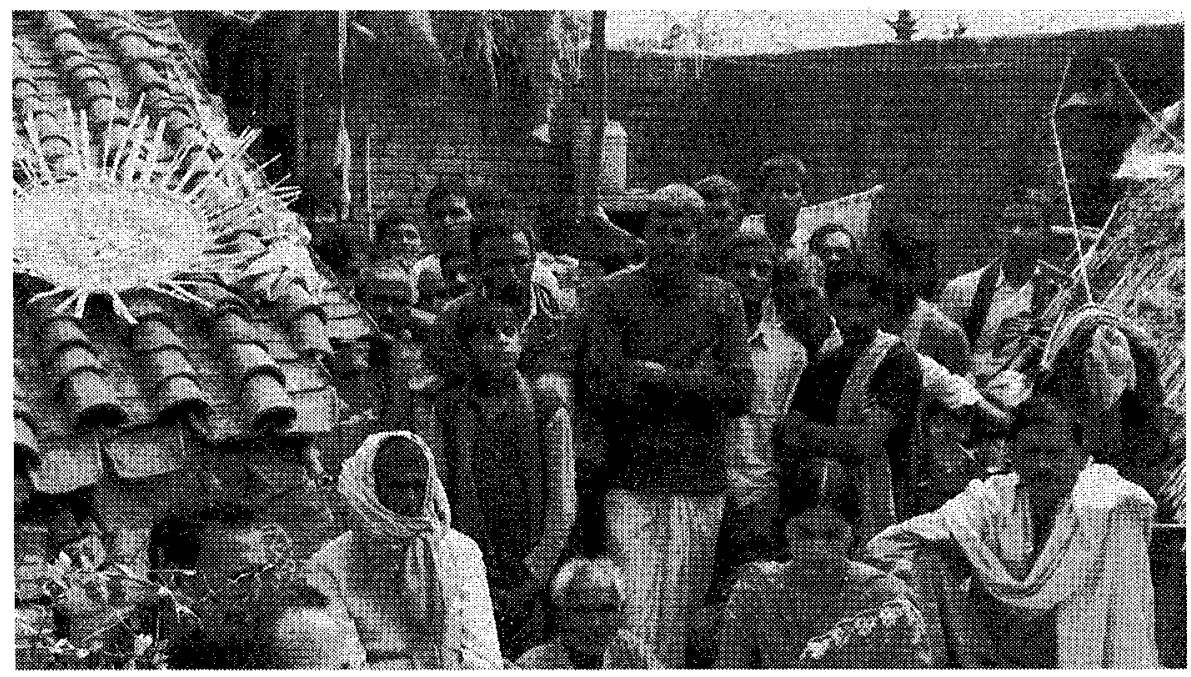

\section{A. Background}

India abolished dowry with the Dowry Prohibition Act. ${ }^{65}$ Yet, dowry remains an important part of contemporary marriage in India. Promoting and protecting family property and wealth are competing and overlapping interests in many Indian marriages. Financial or

64. This photograph was taken by the author.

65. The Dowry Prohibition Act, 1961, No. 28, Acts of Parliament, 1961 (India). Dowry is a gift or money provided by the wife's family to the husband's family. 
"gift" exchanges are often explicit and the consequences for reneging on dowry promises can be severe, including the battery and death of a bride. In an interview, Judge Komal Ram informed me that "dowry has become an accepted evil in society." 66 Marriage brokers as well as matchmakers figure into these sophisticated marriage markets. Financial exchanges pervade many aspects of Indian marriages, often without the consent of the bride.

Thus, one element of this project emerged from my theory that marriages can and do serve as minor sex-trafficking networks, which vary from the somewhat innocuous, involving adults deferring to parental influence over their marriages, to the extreme, including underage girls being forced into marriages with older men. Figure 1 captures the image of a lone sixteen-year-old bride, soon to marry her second husband after the first had died.

Coinciding, then, with my interests and prior works expanding on how human markets form to satisfy "intimacy" needs ${ }^{67}$-be it organs for survival, ${ }^{68}$ surrogates to facilitate exogenous gestation, ${ }^{69}$ or babies to satisfy the need to parent ${ }^{70}$-is the desire to flesh out "on-theground" marriage arrangements in India involving underage children, especially girls.

Thus began the Indian Marriage Market project. As it turns out, marriages follow some of the same conditions and terms economists associate with traditional markets, including scarcity, supply, cost, and demand. Yet, underage-marriage markets are also a space for which traditional economic theory and the nomenclature of economics fail to capture the full scope of the problem.

This Article addresses a portion of that research, focusing on the normative question: Why does underage marriage persist despite law's prohibitions or, in fitting with this Symposium, under what conditions does law fail?

66. Interview with Komal Ram, Sub-Divisional Judicial Magistrate, in Bihar, India (Feb. 19, 2011).

67. See, e.g., Michele Goodwin, Private Ordering and Intimate Spaces: Why the Ability to Negotiate is Non-Negotiable, 105 MrCH. L. Rev. 1367, 1367-69 (2007) (book review).

68. See Michele Goodwin, Black Markets: The Supply and Demand of Body Parts (2006).

69. See generally Baby Markets: Money and the New Politics of Creating Families (Michele Bratcher Goodwin ed., 2010) (discussing the increasing use of market-like processes in reproduction, including surrogacy) [hereinafter BABY MARKETs].

70. Kimberly D. Krawiec, Price and Pretense in the Baby Market, in BABY MarkeTs, supra note 69 , at 41,44 ("For some prospective parents, the desire for a family is so strong that they will stop at virtually nothing to procure a child ...."). 


\section{B. Scope, Approach, and Methodology}

The project engaged in on-the-ground fieldwork in Delhi; Mumbai; Pune; Patna; Varanasi; Trivandrum; the outer, rural reaches of Bihar; Uttar Pradesh; and wrapped up in Kerala. ${ }^{71}$ Prior descriptive accounts of some of the rural communities in India ${ }^{72}$ could not properly place in context the human deprivation, banditry, corruption, and poverty on full display throughout villages: water buffalo and cows sharing the road, men defecating on the sides of paved, then gravel, then dust roads.

In many ways, the rural villagers in Bihar and Rajasthan are the forgotten or the undiscovered among the Indian elite. One female Indian lawyer from Mumbai informed me that prior to seeing my photos from Bihar, she was unaware of the conditions in that state. Indeed, the conditions in rural India are so strikingly dissimilar to the norms in India's crowded cities that their realities are but fiction or dystopia to others.

Included in the project was a wide-ranging review of law, policies, and guidelines relating to child marriage. Anchoring the research were field interviews with judges, police officers, nongovernmental organizations (NGOs), the chief of UNICEF's children's division in India, parents, grooms, and brides. Indeed, what makes this project unique is its conversations with local community members. For example, a recent study commissioned by UNICEF to study child marriage in India included interviews with "key officials," but not on-theground actors who facilitated the marriages, or those coerced or forced into the arrangements. ${ }^{73}$ Nevertheless, UNICEF, the most significant presence actively working to eliminate child marriage, provided consistent and on-going support for this project.

This research was facilitated over two years with two intensive stays in India, separated by a one-year period. An extensive literature review was conducted prior to the launch of the project. ${ }^{74}$ Indeed, it became clear from the literature review that, despite the persistent problem of child marriage, few doctrinal or theoretical accounts have been offered to explain this problem as a failure of law or a failure of federalism. Materials gathered during interviews brought to the fore a few noticeable gaps, including federal investment in anti-child mar-

71. See infra Figure 2.

72. See supra Part I.

73. See UNICEF, Desk Review of ChiLd MARriage 2 (2011), available at http://www.khub marriage18.org/sites/default/files/18.pdf.

74. Id. at 1. This pre-field research period included the arduous process of obtaining approval from the Institutional Review Board. 
riage literature and posters. Interestingly, with India's astoundingly high illiteracy rates in the communities with the highest number of child marriages, such a system does not offer reliable protection. When this matter was brought to a chief legal officer at the National Commission for Women, he replied that "in India, education is compulsory up to [the] age of fourteen."75

\section{TABLE 1: Field Visits}

\begin{tabular}{lcc}
\hline Participants & Location & Federal/State/District \\
\hline $\begin{array}{l}\text { Ministry of Health \& } \\
\text { Family Welfare } \\
\text { National Commission } \\
\text { for Women }\end{array}$ & Delhi & Federal/Central \\
International NGOs & Delhi & Federal/Central \\
Member of & Delhi & Federal/Central \\
Parliament & Bihar & Federal/Central \\
Lawyers & Delhi & Federal/Central \\
Lawyers & Mumbai & State \\
Marriage Parties & Mumbai & State \\
Judges & Bihar & State \\
NGOs & Trivandrum & State \\
NGOs & Delhi & State \\
Police & Bihar & State \\
Judges & Bikramganj & District \\
Lawyers & Bikramganj & District \\
Magistrate & Patna & District \\
Marriage Parties & Bikramganj & District \\
Marriage Parties & Pune & District \\
Marriage Parties & Mumbai & District \\
\hline
\end{tabular}

75. Interview with S.C. Kaushik, Senior Research Officer, Nat'l Comm'n of Women, in Delhi, India (Feb. 22, 2012). 
Figure 2: Political Map of India ${ }^{76}$

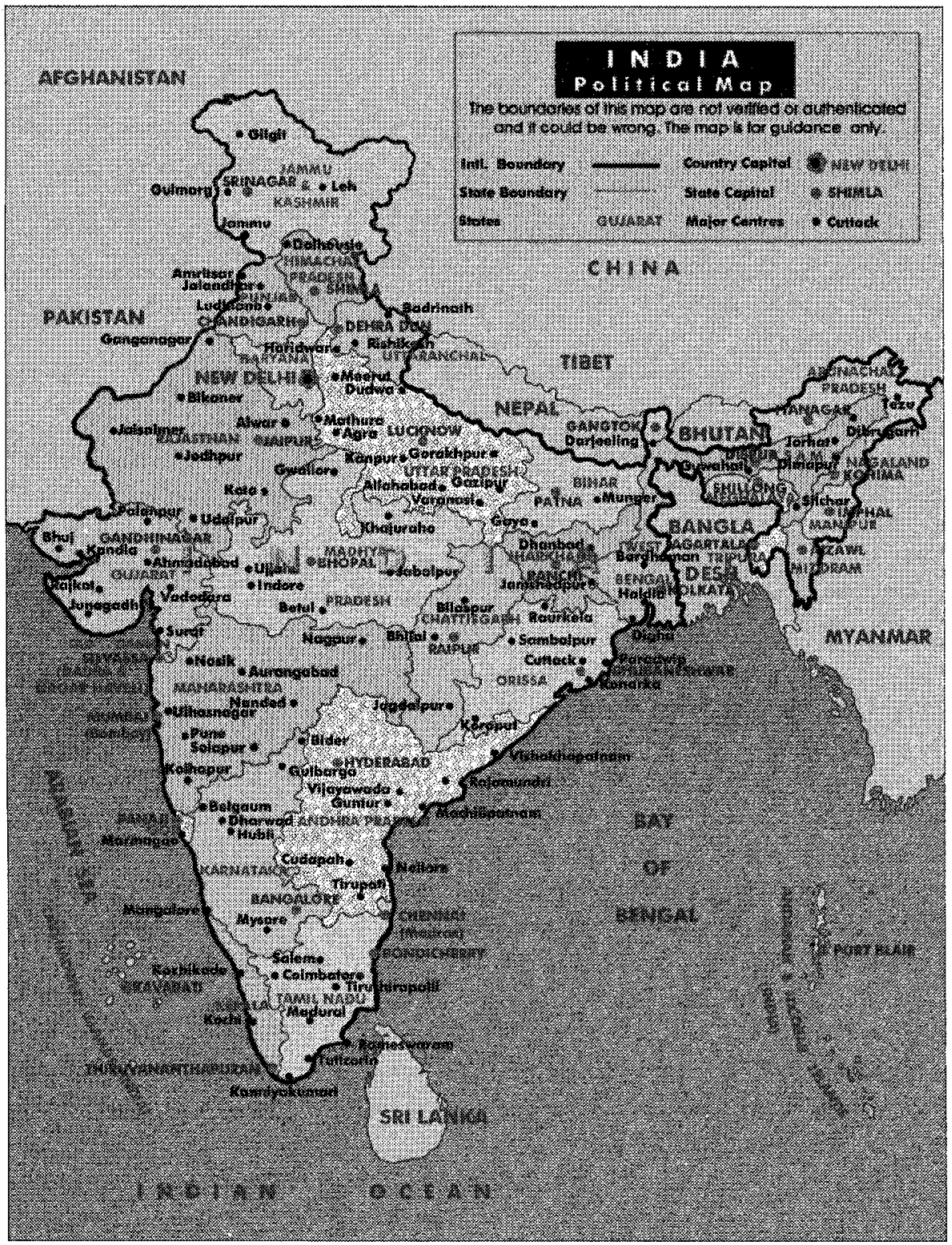

76. Travel India Guide: Poltrical MaP of Indra, http://www.travelindia-guide.com/maps/ political_map.php (last visited Feb. 7, 2013). 


\section{Child Marriage: Poverty, Illiteracy, and Judicial Abrogation}

This project led me into what many describe as the most destitute state in India: Bihar. The social conditions are so abysmal in its rural areas that even the most revered legal institutions and government buildings mire in decades-thick grime and filth. The stench emanating from the buildings, nearly indiscernible from that outdoors, goes unnoticed because it is so much a part of life in this community. Plumbing in these buildings often does not work and has not for years. Buckets serve as makeshift latrines in even the senior judge's chamber. According to a recent survey, in rural communities like Bihar and Jharkhand, as few as $4.9 \%$ of the population used piped drinking water, less than $23 \%$ had electricity, and less than $6 \%$ had toilets. ${ }^{77}$

It is in the dusty villages of Bihar, the state most notorious for child marriage, but also known for illiteracy, banditry, theft, kidnappings, and poverty, that tourists and Indians are warned not to travel into its inner caverns or take the train. ${ }^{78}$ As one commentator recently observed, "Train travel in Bihar has been always fraught with dangers with aggressive ticketless travelers and train robbers looting passengers. Burning down trains is just the latest threat."79 In Bihar, there is little respect for governmental authority, and officials seem somewhat aware of this. In an interview with the British Broadcasting Company (BBC), a bank official explained the risk of travel in Bihar: "Anything can happen to you-you could be robbed, drugged, shot for a seat, thrown out of the coach for refusing a bribe to the police, or have your coach burnt down by an angry mob." 80 The superintendent of railway police confirmed this concern, noting that each day a handful of travelers are drugged and robbed on the trains. ${ }^{81}$ It is with this backdrop that one is introduced to the villages in this vast state and its competing legal regimes, that is, the law of custom versus federal law.

Indeed, for the common reader, life in this region may be difficult to comprehend and this description may seem like an exaggeration. Yet, a picture should be offered to ground this Article and better contextualize why judges who become complicit in attending, performing,

77. See Int'l Inst. Population Sci., Dist. Level Household and Facility Survey: Jharkhand Fact Sheet (2007-2008) [hereinafter Jharkhand Fact SHEet], available at http://www.jsk.gov.in/dlhs3/Jharkhand.pdf.

78. See Amarnath Tewary, Why People Burn Trains in Bihar, BBC NEws, http://news.bbc.co. uk/2/hi/south_asia/8213488.stm (last updated Aug. 24, 2009).

79. Id.

80. Id.

81. Id. 
and certifying child marriages are passive about challenging or overruling custom. Understanding the conditions of their professional and living spaces (apartments are supplied to judges and the state mandates their habitation in the dwellings-even those that are cramped, unsanitary, and without adequate running water) does not fully explain why judges disregard the rule of law by certifying child marriages; judges are imbedded literally and figuratively in these communities. Yet, they are not of the communities, and the villagers (and judges) understand this. However, this brief descriptive account may illume why judges seem eager to rotate on to a new state, require police and security escorts when they travel into the villages, and seem so disenchanted with the power of federal law to make any inroads to compete against local tradition. The problem manifests as a circuitous enigma; local norms are unlikely to change if the interpreters and implementers of federal policy neglect their duties and defer their authority. In several interviews, judges appeared to believe that upholding federal anti-child marriage laws was a useless task.

\section{A. Child Marriage: Conflicting Law}

Efforts to protect children from underage marriage in India date back nearly a century to the passage of the Child Marriage Restraint Act of 1929.82 Twenty-six years later, the Hindu Marriage Act (HMA) ${ }^{83}$ legislatively reaffirmed this priority. One goal in clarifying the minimal age of marriage in India was to prevent a cyclical problem that pervaded states throughout the country: intergenerational preteen and teen pregnancy. Not terribly uncommon, then, is grandparentage occurring in the late twenties and early thirties.

The HMA prohibits the marriage of men and women under ages twenty-one and eighteen respectively, and describes other forbidden marital arrangements, including marrying the insane, epileptic, and currently betrothed. ${ }^{84}$ The HMA functions as India's guiding legislation on marriage, despite numerous overlapping and confusing, if not conflicting, marital laws. ${ }^{85}$ For instance, the Muslim Marriage Act

82. The Child Marriage Restraint Act (CMRA) - also known as the Sharda Act-prohibited child marriages of girls below the age of fifteen and of boys below the age of eighteen. Child Marriage Restraint Act, 1929, No. 19, Act of Parliament, 1929 (India). It was amended in 1978 to increase the age of solemnization from fifteen and eighteen to eighteen and twenty-one for girls and boys respectively. See The Child Marriage Restraint (Amendment) Act, 1978, No. 2, Acts of Parliament (India); see also Asha Bajpai, Child Rights in India: Law, Policy, AND Practice 220-21 (2003).

83. See The Hindu Marriage Act, 1955, No. 25, Acts of Parliament, 1955 (India).

84. Id. $\S 5$.

85. See marriage laws cited supra notes $55-59$. 
(MMA), also enacted in 1955, does not impose an age prohibition on marriage. ${ }^{86}$ Instead, it requires that both parties be Muslim in order to qualify for marriage. ${ }^{87}$ The MMA does not explain the prevailing Hindu practice that celebrates child marriage. However, the MMA and other competing marriage laws expose descriptive problems between various Indian marital laws, which pose normative challenges.

Thus, religion confuses India's marriage laws and practices. In fact, the All-India Muslim Personal Law Board claims that "in family matters the country's Muslims should be subject only to Islamic law." 88 That organization and those similar to it point to a 1937 act instantiating Muslims' right to be governed by their own rule in India. ${ }^{89}$ That Muslims comprise the largest minority population in India brings this internecine conflict into sharp contrast. According to some Muslim interpretations of Sharia, girls may marry as young as twelve years old (even younger if they have experienced puberty). ${ }^{90}$ In an interview, one former Muslim child bride voiced confusion over the legal conflict between the federal rule requiring adulthood for marriage and the MMA, advocating that "the sooner a girl gets married, the better." 91 The bride's father-in-law explained the law's relevance: "Women are like creeper plants that latch onto any tree they find-whether it's a good tree or a bad tree. Once they get to puberty they are always in danger of falling into bad ways." 92

Subsequent to the HMA's ratification, successions of federal laws were enacted to curb the incidence of child marriage, including the Child Marriage Restraint (Amendment) Act,,$^{93}$ and most recently, the Prohibition of Child Marriage Act of $2006 .{ }^{94}$ Krishna Tirath, the Minister of Women and Child Development, acknowledged that "despite the law, child marriages continue[] to take place." 95 In a recent UNICEF handbook meant to communicate the perils of underage marriage, Minister Tirath noted, "There are many marriages in which

86. Muslim Marriage Act, 1957, No. 53, Acts of Parliament, 1957 (India).

87. Id. \& 6 .

88. Charles Haviland, Battle Over India's Marriage Age, BBC News (Sept. 5, 2002), http:// news.bbc.co.uk/2/hi/south_asia/2238321.stm.

89. Id.

90. Id.

91. Id.

92. Id.

93. The Child Marriage Restraint (Amendment) Act, 1978, No. 2, Acts of Parliament, 1978 (India).

94. The Prohibition of Child Marriage Act, 2006, No. 6, Acts of Parliament, 2007 (India).

95. See Ministry of Women \& Child Development, Handbook on the Prohibition of ChIld Marriage ACT, 2006, at 3 (2006), available at http://www.unicef.org/india/Child_Marriage_handbook.pdf. 
both the girl and the boy are children. In others the girls are children/ minors who are married off to much older men, or sometimes even sold into marriage." 96

\section{B. The High Incidence of Underage Marriage}

Child marriage is a deeply entrenched custom and phenomenon in India. Over $40 \%$ of women between the ages of twenty and twentyfour report that they married under the legal age of consent. ${ }^{97}$ Importantly, this figure represents a decline in most states from $54 \%$ of Indian girls forced into underage marriages twenty years ago. 98 This decline, however, could mask the severity of child marriage in India's rural communities, where the externalities of child marriage range from sexually transmitted diseases and teen pregnancy to domestic violence perpetrated both by husbands and mothers-in-law against young brides.

Child marriage exposes an imbedded gender dynamic as well. Families marry sons under the legal age required by law, but such practices are less common than girls forced into marriage. As a government report noted, "Men in the same age group [as women] get married... at a median age of 23.4 years. Sixteen percent of men aged 20-49 are married by age 18 and [28\%] by $20 . " 99$ Figure 3 provides a visual account of marriage trends in India. In 2007-2008, the most recent period for which this federal data was collected, $42.9 \%$ of women reported being wed under the legal age of consent. ${ }^{100}$

96. Id.

97. Interview with Jose Bergua, Chief of Child Protection for India, UNICEF, in Delhi, India (Feb. 23, 2011).

98. Child Marriage, supra note 13.

99. Int'l Inst. Population Sci., National Family Health Survey, at xxxi (2005-2006).

100. See Int'l Inst. Population Sci., District LeVel Household and Facility SURVEY 2007-08, at 17 tbl.2.7 (2010) [hereinafter DLHS], available at http://www.rchiips.org/pdf/INDIA_ REPORT_DLHS-3.pdf. The same data indicates that the percentage of underage marriages in rural areas is as high as $48 \%$. See id. 
Figure 3: Percentage of Women Ages 20-24 Married

Before Age 18, By Year ${ }^{101}$

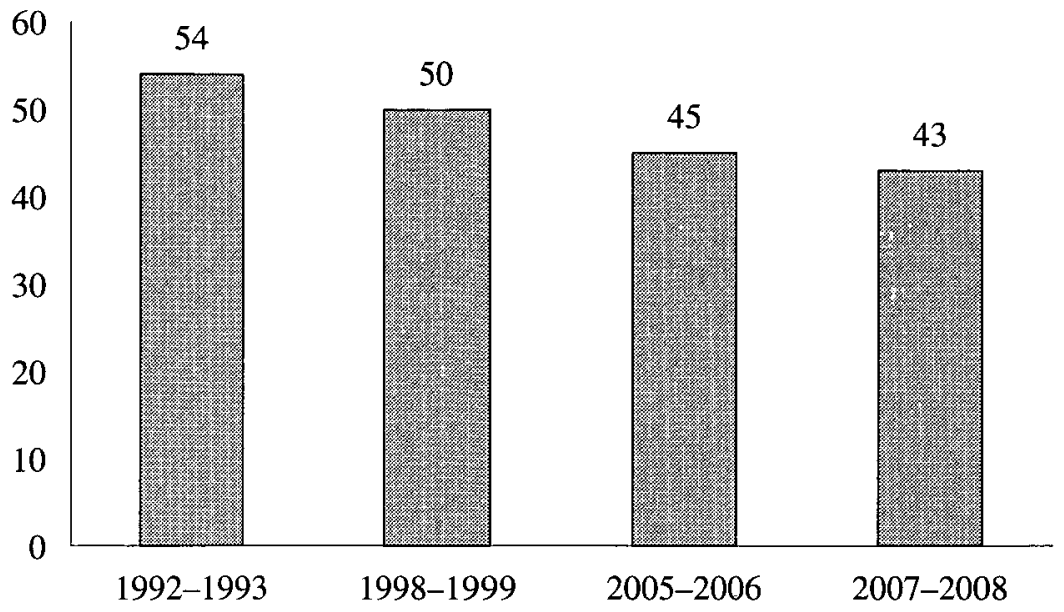

Indeed, the states with the highest rates of child marriage were among those where field research for this project was conducted, including Bihar and Uttar Pradesh. West Bengal, Rajasthan, Jharkhand, Andhra Pradesh, Karnataka, and Madhya Pradesh share the unfortunate distinction as the states wherein at least one in two girls will marry before her eighteenth birthday, and many before the age of ten or eleven to avoid puberty and ensure purity. ${ }^{102}$ Often, these marriages are facilitated by "mass weddings" on special Hindu holidays, such as Akha Teej. ${ }^{103}$

A report by the BBC pointed to the scope of the problem: "On auspicious days in the Hindu calendar it is not uncommon for thousands of children, including babies, to be married, despite laws already in place designed to prevent such practices."104 These marriages are not conducted as surreptitious ceremonies in covertly concealed, clandestine locations. To the contrary, child marriage is a conspicuous secret in full view of local authorities.

101. Child Marriage, supra note 13.

102. See id. at 1-2.

103. Akha Teej is an auspicious time of celebration in India, which is frequently celebrated by marriage ceremonies. In recent years, law enforcement organizations in India target this holiday as an opportunity to stop child marriages. See Alastair Lawson, Child Marriages Targeted in India, BBC News (Oct. 24, 2001), http://news.bbc.co.uk/2/hi/south_asia/1617759.stm.

104. Id. 
Figure 4: Percentage of Women Ages 20-24 Married Before Age 18, By State ${ }^{105}$

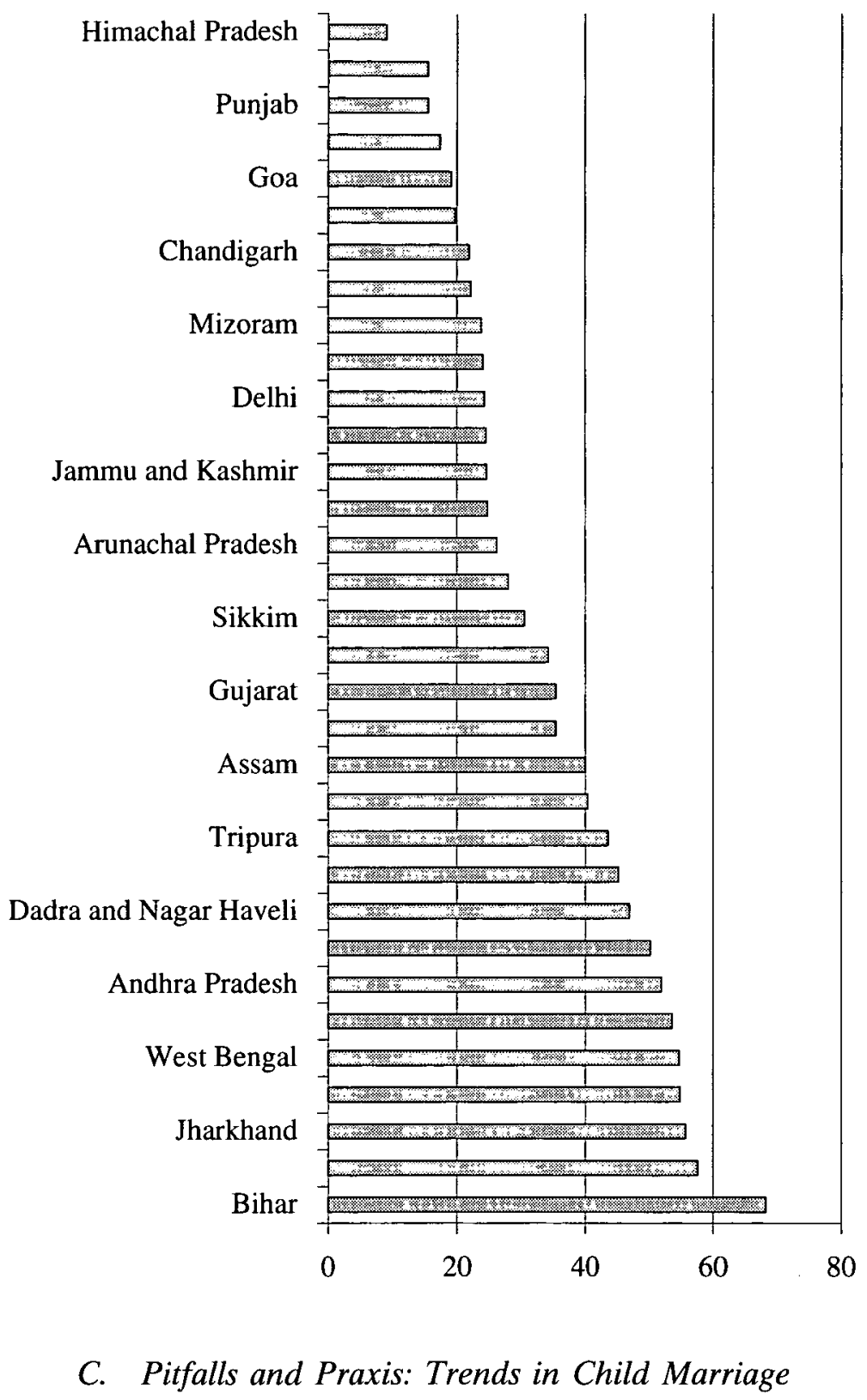

A compelling piece of literature documented the pitfalls of child marriages, particularly for developing nations. Not surprisingly, the

105. Child Marriage, supra note 13. 
highest rates of child marriage correlate with illiteracy and lack of educational attainment. ${ }^{106}$ Noticeably then, high-literacy states such as Kerala report among the lowest incidences of child marriage. ${ }^{107}$

The District Level Household and Facility Survey (DLHS) provides essential information to NGOs working on behalf of women's and children's rights. The survey is one of the largest demographic and health studies carried out in India. The first survey, administered by the Ministry of Health and Family Welfare (MHFW), was conducted "in 1997 to provide district level estimates on health indicators to assists [sic] policy makers and program administrators in decentralized planning, monitoring and evaluation."108 The organization is now on its third national survey. The empirical data illuminate important details about the literacy of households, age of marriage, size of families, and even prenatal care. In some ways it functions as a census on the status of women in India. For this project, the DLHS helped to illustrate trends in education and knowledge about government health programs, marriage, fertility, and other relevant issues.

Trends in child marriage follow key demographics, such as education, habitation (rural versus urban), poverty, and caste. The DLHS reported that although child marriages occur with high frequency throughout India, a striking disparity is distilled by comparing rural areas to their urban counterparts. ${ }^{109}$ For instance, "[c]hild marriage ... affects girls in rural areas $(48 \%)$ more than in urban regions (29\%)."110 Figure 4 further illustrates this point. Even within the same geographical demographic, girls from scheduled castes, tribes, and economically disenfranchised households generally marry at a younger age. ${ }^{111}$ The average age of marriage for a woman with at least the equivalent of a high school diploma is roughly twentythree. ${ }^{112}$ By contrast, the highest age of marriage for women of the lowest caste is about fifteen. ${ }^{113}$

106. Compare id., with Literacy Rate in India, MAPS OF INDIA, http://www.mapsofindia.com/ census2011/literacy-rate.html (last visited Feb. 7, 2013).

107. Child Marriage, supra note 13. In 2011, the female literacy rate was $91.98 \%$. Kerala Population Census Data 2011, Population Census India, http://www.census2011.co.in/census/ state/kerala.html.

108. See Int'l Inst. Population Sci., District Level Household and Facility Survey: Uttar Pradesh Fact Sheet 2 (2007-2008), available at http:/www.mchstar.org/pdf/whereWe Work/DLHS3UPFactSheet.pdf.

109. See DLHS, supra note 100 , at xxii.

110. Child Marriage, supra note 13.

111. Id.

112. Id.

113. Id. 
Why have many Indian communities participated in practices that ultimately deny educational attainment to girls? Why marry them early? Chief among their considerations are financial constraints. Families believe that facilitating an early marriage relieves them of their daughter's economic burden, ${ }^{114}$ but this belief is grounded in two key matters. First, in rural areas, parents are less likely to educate their daughters, thereby limiting their daughters' practical skills. Second, because their daughters lack both practical and more advanced skills that can generally only be obtained with an education, a pernicious cycle is born. Moreover, if an education is not afforded to a girl prior to exiting her parents' home, one will not be afforded to her while living with her in-laws.

\section{Child Marriage and Education}

The pitfalls of underage marriage include educational deprivation. Families perceive investing in girls' education to be an inappropriate use of resources or a "waste."115 A commonly voiced concern during my interviews was that "a girl's education will only benefit her husband's household, and not the family of origin."116 This perception, coupled with educational deprivation, harms not only young women, but their families, the state, and India. Still, rural families remain reluctant to educate their daughters for various reasons. In dangerous districts, for example, parents confided their fears to me, including reluctance to allow their daughters to walk or bicycle alone to school, concerned that the girls might be verbally assaulted, physically abused, sexually coerced, or raped. ${ }^{117}$

Measuring the depth and legitimacy of these concerns is not easy to do, especially as the dangers of sexual violence and exploitation in some rural communities inure a palpable threat, both real and apparent. ${ }^{118}$ In other words, although girls are the victims of "tradition" in restricting their access to schooling, their parents' concerns about sex-

114. Id. at 2 .

115. $I d$.

116. See Child Marriage, supra note 13 , at 2.

117. Interview with community women, in Bihar, India and Bikramganj, India (Feb. 18-19, 2012); Interview with Jose Bergua, supra note 97 . Recently reported gang rapes of adult female students in India lend further credibility to parents' concerns. See Jason Burke, Indian Police Investigate Two Gang Rape Cases, GuARDIAN (Jan. 13, 2013), http://www.guardian.co.uk/world/ 2013/jan/13/indian-police-investigate-gang-rape.

118. See Ministry of Women \& Child Development, supra note 95, at 6. The Ministry observed:

Parents justify early marriage as a way to protect the girl child from violence. However, parents do not understand that child marriage actually opens the door to an endless and vicious cycle of domestic violence and abuse. Marriage is also often used as 
ual violence deserves state attention. In the months since my stay in Bihar, a brutal gang rape of a woman who exited a train in Bihar has captured international attention; the victim was sexually assaulted and murdered by a group of men. ${ }^{119}$

Several weeks prior to the January 11, 2013 gang rape and murder in Bihar, on December 16, 2012, a medical student's brutal gang rape and murder on a bus in Delhi, the nation's capital, also captured international attention. ${ }^{120}$ That case epitomizes India's hopes and fears regarding women; the female medical student defied traditional norms (and low expectations) that purport women to lack the requisite intellectual capacities to succeed at graduate study, and yet even her status could not overcome a more general vulnerability of women in India to widespread violence. ${ }^{121}$ In fact, the local government in Delhi recently reported hiring hundreds of guards to post outside of over 500 elementary schools, because parents reported their daughters being stalked, harassed, and sexually violated after school by men who wait outside the schools and follow girls home.122 Manish Gupta, Commissioner of South Delhi Municipal Corporation, which oversees Delhi's elementary schools, explained in a news report, "We have planned to deploy private security guards, from government-approved agencies, in primary schools by the next academic year after several cases of molestation came to our notice ....We are taking this step in order to draw the girl students back to school." 123 Generally, reported cases of rape have increased by $20 \%$ between 2007 and 2011,124 and those cases involving school-aged girls and college students have become more visible in recent years. ${ }^{125}$ Importantly, some parents view

\footnotetext{
the first step to trafficking for commercial sexual exploitation, forced labour or any other purpose.

Id.
}

119. See Burke, supra note 117.

120. See Delhi Gang Rape Victim's Funeral Held, BBC News, http://www.bbc.co.uk/news/ world-asia-india-20869185 (last updated Dec. 30, 2012, 3:54 PM).

121. See Annie Banerji, In Indian Student's Gang Rape, Murder, Two Worlds Collide, Reuters, Dec. 31, 2012, available at http://uk.reuters.com/article/2012/12/31/uk-india-rape-attack-idUKBRE8BU02A20121231.

122. Delhi Primary Schools to Hire Guards for Girls' Security, NDTV, http://www.ndtv.com/ article/cities/delhi-primary-schools-to-hire-guards-for-girls-security-303147 (last updated Dec. 9, 2012).

123. Id.

124. Olga Khazan, How India's Rape Name-and-Shame Database Could Backfire, WASH. Post (Dec. 28, 2012, 11:15 AM), http://www.washingtonpost.com/blogs/worldviews/wp/2012/12/ 28/how-indias-rape-name-and-shame-database-could-backfire. The increased incidence of rape could be a manifestation of better reporting mechanisms and women feeling more courageous to report sex abuse. On the other hand, there could genuinely be an increase in rape.

125. See id.; Burke, supra note 117. 
schools as a dangerous place for their daughters and justify restricting school as a means of keeping their girls safe. ${ }^{126}$ The result, however, is that nearly $70 \%$ of women in some rural communities are illiterate when they marry. ${ }^{127}$

Two interesting points of contrast can be illumed from this data: (1) the incredibly low percentage of women in rural marriages as compared to women in urban marriages with a high school diploma equivalent-less than 7\% ${ }^{128}$ - and (2) the sharp disparity between educational attainment for women in urban versus rural areas. ${ }^{129}$ The data did not paint a panacea in urban areas, but the contrasts are nonetheless striking between the urban areas and rural communities. In Jharkhand, nearly $70 \%$ of rural married women were illiterate, while this figure was fewer than $30 \%$ in the district's urban reaches. ${ }^{130}$ In fact, over $40 \%$ of married women in the urban community's population have ten or more years of education. ${ }^{131}$

Importantly, if girls are denied the opportunity for education, the gap is filled by something else. NGOs point to compelled childbearing and isolation as the consequences of denying girls education. Indeed, if previously enrolled, child brides are often forced to drop out of school to work for their in-laws. ${ }^{132}$ According to UNICEF, when child brides leave school, they are "exposed to higher risk of domestic violence and abuse, increased economic dependence, denial of decision-making power, [and] inequality at home, which further perpetuates discrimination and low status of girls/women."133

\section{Child Marriage and Health}

Child marriage is also associated with significant health risks and consequences for adolescent and barely pubescent girls. Early marriage typically results in repeated pregnancies. These pregnancies

126. See Delhi Primary Schools to Hire Guards for Girls' Security, supra note 122.

127. JHARKhand FACT SHEET, supra note 77 (noting that, in 2007-2008, 68.2\% of married women from ages fifteen to forty-four in rural Jharkhand were illiterate); see also DLHS, supra note 100 , at 32 tbl.3.1. Note also in Bihar:

- $39 \%$ of all women are allowed to go by themselves to the market;

- $36 \%$ are allowed to go by themselves to a health facility;

- $30 \%$ have freedom to travel outside their own village or community by themselves;

- $25 \%$ of women are allowed to go alone to all three of these places.

Int'l Inst. Population Sci., National Family Health Survey India 2005-06: Bihar 25 (2008), available at http://www.rchiips.org/NFHS/NFHS-3\%20Data/Bihar_report.pdf.

128. DLHS, supra note 100 , at 34.

129. Id.

130. JHARKhand Fact SheEt, supra note 77

131. Id.

132. See Child Marriage, supra note 13 , at 2.

133. Id. at 1 . 
tend to occur before full physical maturation, thereby causing significant complications. For example, $66.6 \%$ of girls between the ages of fifteen and nineteen experience childbirth complications, compared to $59.7 \%$ of women between the ages of thirty and thirty-four. ${ }^{134}$ They are also more likely to experience neonatal complications and high infant and child mortality rates. The graph below illumes some of the child-bearing-related health challenges posed by underage marriage.

Figure 5: Child Mortality Rates by Age of MOTHER IN 2005-2006

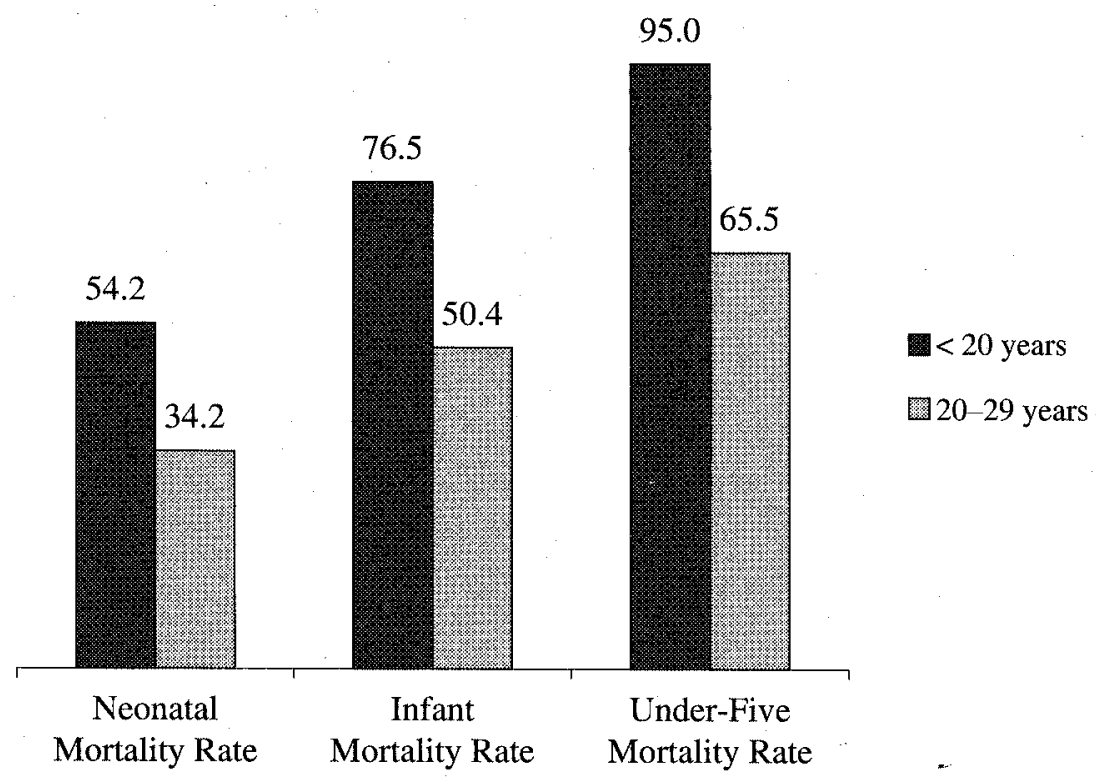

Consequently, not only are underage wives worse off because they lack education, but they are also exposed to more health harms. Figure 5 indicates that the children of women who marry underage are also worse off. "For instance, for young children under the age of [five] years, the risk of malnutrition (stunting and underweight) is higher in children born to young mothers ... than in those born to women married after the legal age."136

Physical health harms extend to threats of violence. For example, girls forced into underage marriages are more likely to be victimized in the household. Consider the following:

134. Id.

135. $I d$. at 2.

136. $I d$. 
Often [ill-equipped] and under-valued, adolescent girls married early are at risk of experiencing domestic violence. NFHS 3 data shows [sic] $56 \%$ of women age $15-49$ in Bihar have experienced physical or sexual violence. It is also a [well-known] fact that young brides are subjected to much abuse because of their inability to cook properly, refusal to have sexual intercourse and inability to work copious amounts. More than half the women $(57 \%)$ in the age group 15-19 believed that a husband was justified in hitting his wife $\ldots .137$

Physical abuse such as that described above may be initiated by young brides' mothers-in-law as well as the husbands. In my interviews, it became very clear that the function of new brides was to clean and serve their in-laws, especially their mothers-in-law who become the "haves" while brides become the "have-nots."

\section{A Persistent Problem Despite Legislative Action}

When studying underage marriage in India, it becomes clear that multiple layers of complicity overlap. Parents violate federal law to marry their daughters to the best situated grooms. Matchmakers facilitate the connections between grooms (and parents) and the brides' families. ${ }^{138}$ Such practices also extend to the United States. ${ }^{139}$ Judges certify the marriages in violation of the HMA and the Prohibition of Child Marriage Act. Given the enactment of federal laws prohibiting underage marriage, combined with the negative impacts of the practice, particularly on women, why does it persist? Why is child marriage still rampant in India? Is there a doctrinal account or theory that can rationalize this practice?

On one hand, the frequency of rule making in India demonstrates a confidence that governmental rule making can foster change, at least among legislators. It also points to legislators recognizing the depth and externalities of the nation's child-marriage market. Additionally, legislative action and formal law reflect agreement, collaboration, and mutuality or shared opinion on a critical set of issues. In this case, the dangers of child marriage are apparent at the federal legislative level.

137. UNICEF, supra note 73, at 92-93.

138. See Susan Donaldson James, Wife Sues In-Laws, Says Arranged Marriage Turned to Slavery, ABC News (Jan. 24, 2012), http://abcnews.go.com/Health/wife-sues-laws-alleging-arrangedmarriage-turned-human/story? id=15342407\&singlePage=true\#.T4xWjdXBWF8 (reporting on the lawsuit brought by Diptiben Mistry, who sued her parents-in-law, Chandrakant and Nilam Udwadia, in the U.S. District Court for the Western District of Oklahoma for keeping her as a "virtual prisoner"). In fact, arranged-marriage brides may generally know little about their prospective grooms and future parents-in-law; they are generally removed from these processes even in the most sophisticated and highly educated families. See id.

139. Id. 
With this in mind, legislators should be commended for advancing anti-child marriage legislation and platforms.

On the other hand, when the crude practice of child marriage persists despite multiple layers of laws condemning, prohibiting, and penalizing the practice, a crisis in the rule of law is at hand. It is a sign of institutional failure. In other words, that child marriage not only persists, but is a rampant feature of national life, exposes key weaknesses in India's rule of law. What explains it?

The Indian government has demonstrated a commitment to ratifying and enacting laws to protect children. The Indian Constitution guarantees basic rights to all children regardless of socioeconomic status, cultural affiliation, and "geo-political" situation. ${ }^{140}$ For example, the Indian government enacted the National Plan of Action for Children in 2005 and the Ministry of Women and Child Development aimed to "eliminate child marriages by $2010 . " 141$ Internationally, "India is signatory to several international human rights instruments that protect children from all forms of abuse and exploitation and ensure them the right to dignity and childhood," 142 including the U.N. Convention on the Rights of the Child (UNCRC), ${ }^{143}$ Convention on Elimination of All Forms of Discrimination Against Women (CEDAW), ${ }^{144}$ and the International Covenant on Economic, Social and Cultural Rights (ESCR). ${ }^{145}$ This rule making reveals a commitment to the rights of children. But it may also illume a commitment to rule making. In other words, it may be that the rule-making process serves governmental interests and not outcomes-outcomes may be secondary to a national or federal interest in simply enacting rules.

Although child marriage is the example deployed here, India's civil rights laws "protecting" women provide an equally compelling example. Indeed, Indian legislative protections for women may be among some of the more nuanced and progressive laws enacted anywhere in the world to prohibit domestic violence, ${ }^{146}$ sexual harassment, ${ }^{147}$ dowry, ${ }^{148}$ the indecent representation of women, ${ }^{149}$ and the immoral

140. Ministry of Women \& Child Development, supra note 95, at 7.

141. $I d$.

142. Id.

143. United Nations Convention on the Rights of the Child, Nov. 20, 1989, 1577 U.N.T.S. 3.

144. United Nations Convention on the Elimination of All Forms of Discrimination Against Women, Dec. 18, 1979, 1249 U.N.T.S. 13.

145. International Covenant on Economic, Social and Cultural Rights, Dec. 16, 1966, 993 U.N.T.S. 3.

146. See The Protection of Women From Domestic Violence Act, 2005, No. 43, Acts of Parliament, 2005 (India).

147. The Protection of Women Against Sexual Harassment at Workplace Bill, 2007 (India).

148. The Dowry Prohibition Act, 1961, No. 28, Acts of Parliament, 1961 (India). 
trafficking of persons. ${ }^{150}$ Yet the National Crime Records Bureau provides a chilling account of harms against women in India that range from the rarer but extreme and barbaric acid throwing, to rampant sexual assault, marital rape, and domestic violence. Such violent acts against women occur frequently in spite of law.

One way to explain this phenomenon, in which law does not lead to social change or to social justice for the most vulnerable in society, is suggested by Marc Galanter, that is, the "haves" really do come out ahead. In this way, we can imagine that given India's deeply entrenched gender problems, and subordination of women in work and home, men will always come out ahead. This, then, could explain the two stories of pro-women's rights laws failing to protect women and anti-child marriage laws succumbing along the same lines. Though it may be compelling, this is an incomplete explanation-a half-painted portrait.

\section{A. Crying Wolf}

The failure of India's laws to effect actual change may point to the "overuse" of legislation. In other words, too much legislation may produce an anesthetizing or numbing effect. Here, marriage legislation may be perceived as crying wolf to disinterested, disenchanted, and disbelieving citizens. Accordingly, the legislature has lost its credibility, much like the boy who cried wolf. Frequent legislation on child marriage without enforcement likely produces an effect similar to that which juries experience upon learning that a plaintiff is a repeat personal injury litigant. ${ }^{151}$

Interestingly, when legislatures fail to implement the appropriate enforcement mechanisms, not only do such efforts produce a perverse effect-the trouncing of new law-but they may also inadvertently cause those whom the law was intended to protect to lose confidence in the legislative process. As a consequence, the law fails to bring about or produce the legislatively intended effect.

Crying wolf at the federal legislative level may shape local government perceptions about the capacity of the central legislative process to bring about social change. This becomes particularly relevant for the judges and law enforcement officers who are responsible for inter-

149. The Indecent Representation of Women (Prohibition) Act, 1986, No. 60, Acts of Parliament, 1986 (India).

150. The Suppression of Immoral Traffic in Women and Girls Act, 1956, No. 104, Acts of Parliament, 1956 (India).

151. See generally Galanter, supra note 1 (studying the outcomes of repeat players in litigation). 
preting and implementing law. The danger in repeat legislation is that it eventually functions as symbolic rather than substantive.

\section{B. Local over Central}

India's challenge in overcoming a legacy of child marriage can also be explained by custom trumping federal law. Frequently, during interviews in India, government officials, NGO leaders and activists, and citizens reminded me that custom is as important, if not more so, than federal law. This perception helps to explain the blatant disregard for federal prohibitions on child marriage.

Dowry has figured significantly in Indian customs that predate legislative action to tamp down on child marriage, thus families are motivated to play the dowry market successfully. In other words, the dowry practice may perpetuate child marriage because it encourages parents to "sell off" their daughters earlier than later, figuring that the older and more educated young women become, the more difficult it will be to secure marriages. More educated girls generally demand a more significant dowry. The perverse consequences of dowry include early marriage and suppressing education to gamble that a daughter will be married and not "over-priced" for the marriage market. Dowry is proscribed by the Dowry Prohibition Act of 1961, but the practice is a widespread "evil," according to a Bihar judicial magistrate. ${ }^{152}$

\section{A Gendered Economic Problem}

Child marriage in India also reveals a deeply entrenched gender problem. According to one commentator, "The sad fact is that in India, ... a cocktail of female infanticide, dowry deaths, trafficking and domestic violence creates a toxic environment for women (the world's fourth most dangerous country for women ... according to Thompson Reuters foundation)."153 This gender problem touches on both education and marriage. Jose Bergua, the Chief UNICEF Officer in charge of matters relating to children, reiterated a theme commonly heard throughout India: "Girls are perceived as an economic burden" unlike boys who are perceived as a family's investment. ${ }^{154}$ Indeed, the perception that girls are property, or "paraya dhan," belonging to the marital family reinforces the urgency to marry girls as quickly as possi-

152. Interview with Komal Ram, supra note 66.

153. Jen Swanson, Indian Girls Are Married Off to Avoid Becoming Prostitutes, SLATE (Apr. 2, 2012, 1:56 PM), http://www.slate.com/articles/double_x/doublex/2012/04/indian_girls_become child_brides_instead_of_prostitutes_html.

154. Interview with Jose Bergua, supra note 97. 
ble. By marrying girls at the youngest age possible, a family reduces the investment costs in their daughters.

Families' concerns about investing in girls are further demonstrated by the reluctance to educate daughters. Again, "[i]nvesting in girls" education is not considered worthy," as girls move to the groom's household and are employed in fulfilling his family's chores. ${ }^{155} \mathrm{Be}$ cause girls suffer the fate of illiteracy, which ultimately deprives them of non-menial work opportunities, marriage becomes one of the few options for young women.

Finally, weddings are a lavish expression of cultural norms in India. Sonia Gandhi, a leader in India's Congress, recently spoke out against the "ostentatious" shows of wealth that commonly accompany Indian marriages. ${ }^{156}$ Even the very poor cannot escape it. Parents attempt to marry daughters early and in group weddings to reduce costs. ${ }^{157}$ Some families will even try to marry all the daughters at the same ceremony to limit expenses. ${ }^{158}$ According to UNICEF, poor families even combine weddings with funerals to defray costs. ${ }^{159}$

\section{Reducing the Incidence of Prostitution}

The prevalence of children trafficked into prostitution is a hidden secret in India. Some families and community leaders regard early marriage as a less offensive and safer alternative to the sexual trade. In a world of less-than-ideal options, child marriage is often perceived as the lesser of compromised or burdened options. Mittal Patel, Secretary of Vicharta Samuday Samarthan Manch, an Ahmedabad-based NGO, framed it as follows: "If a daughter is not engaged or married by the time she's [ten] years old, she'll be pushed into the flesh trade." 160 One commentator noted, "Often it's the mothers who did the pushing, as the families were desperate for some income."161

Prostitution follows a similar dynamic to that of child marriage; the younger the girl, the better likelihood that she will be picked. Families that choose to prostitute their daughters, rather than marry them off, begin the process early in the developmental lifecycle of a girl-generally about the age of ten.

155. See Child Marriage, supra note 13, at 2.

156. See India Looks to Cut Food Wastage at Weddings, DaILy TelegrapH (Mar. 22, 2011), at 16, available at http://www.telegraph.co.uk/news/worldnews/asia/india/8398383/India-considers-introducing-law-restricting-wasted-wedding-food.html.

157. Child Marriage, supra note 13, at 2.

158. Id.

159. $1 d$.

160. Swanson, supra note 153.

161. Id. 


\section{E. Enforcement}

India's child marriage problem exists in part because of a failure of government. At its most obvious, the failure of government is a failure of enforcement. In other words, were efforts to secure the promise of its laws in place and enforcement mechanisms launched, the threat of criminal sanctions might reduce child marriages. Here, however, I mean to suggest that something more basic and yet more fundamentally flawed is occurring. That is, the government's governing process is compromised by an inability to enforce its legislation and by an incapacity to delegate resources and human capital to address child marriage. This inability does not appear to be an economic obstaclealthough that might be a reasonable explanation. For now, it is an empirical question. Were enforcement measures against child marriage more rigorously pursued, states might better calculate the costs (human, economic, and political) of saving children from the grasps of child marriage.

\section{Institutional Arrangements and the Perversion OF JUSTICE}

India's rural villages are mired in hopelessness. These are not the bucolic spaces romanticized by terms like country, rustic, or pastoral, especially when juxtaposed to "urban." These are not sleepy districts where doors never close in the evenings and locks never turn to secure a latch. To the contrary, some of India's most notorious child marriage districts are rife with illiteracy, poverty, violence, prostitution, kidnapping, and other forms of petty and more organized crime. The lawlessness in Bihar, for example, significantly exceeds the gang warfare of the most notorious U.S. cities. ${ }^{162}$

It is against this backdrop that judges determine their level of investment in upholding federal law, how much they will tolerate custom that conflicts with federal law, and what roles (and personal investment) they will provide in these districts (from which they will rotate in a matter of a few years). Thus, judges present one of the more significant barriers to law flourishing in rural Indian communities. Participating in child marriages contradicts their roles and duties in guarding against child marriage and protecting the interests of children. Compromised, then, is not only the perception of the bench as a source and fount of justice, but also the human rights of children forced into marriages with adults.

162. Cf. Tewary, supra note 78 . 
In Bikramgranj, judges informed me that they felt helpless. ${ }^{163}$ They perceived nothing in their power that could change the conditions into which the rural children were born. ${ }^{164}$ The children's lives were a fait accompli. Stopping a sixteen-year-old girl from marrying a second husband because the first died would not, in their minds, enhance the girl's life prospects. ${ }^{165}$

In other words, judges have lacked confidence in the power of law to significantly better the conditions into which children in poverty are born, including those in the districts where they served. And they have lost their discernment or ethical compass. One judge explained child marriage as a condition of being from a low caste, and therefore nothing that law could change. ${ }^{166}$

Judges are essential to the practice of interpreting and implementing law. Yet, in rural India, their perceptions and behaviors as interpreters of law beg the question of whether providing girls with more law reduces inequality or creates the pathways for equal opportunity and status enhancement. Or is it, as Thomas Carothers suggested, that "Western policy makers and commentators have seized on the rule of law as an elixir for countries in transition"? ${ }^{167}$ It is likely both. Balakrishnan Rajagopal argued that the enthusiastic embrace of the rule of law by human rights activists and others is motivated by "a desire to escape from politics by imagining the rule of law as technical, legal, and apolitical."168

Child marriage in India exposes law's competing and sometimes collaborating forces, such as custom or tradition, religion, poverty, corruption, war, sexism, racism, caste, and tribal conflict. Any one of these elements can undercut the sturdiness and durability of "good" law. In cooperation, these competing forces can and will derail law. Adherence to custom, corruption among judges, sexism, and poverty undercut decades of efforts to effectively implement legislation on behalf of children.

India is at a crossroads where creating more law will neither enable the rule of law to flourish nor create the conditions under which minimal inroads can be established. If judges are essential to the promotion of justice, the mediation of peace, and the reduction of harms, but

163. Group Interview in Judicial Chambers, in Bihar, India (Feb. 19, 2011).

164. $I d$.

165. Id.

166. Interview with Komal Ram, supra note 66.

167. Thomas Carothers, The Rule of Law Revival, Foreign AfF., Mar./Apr. 1998, at 95, 99.

168. Balakrishnan Rajagopal, Invoking the Rule of Law in Post-Conflict Rebuilding: A Critical Examination, 49 WM. \& MARY L. Rev. 1347, 1349 (2008). 
abrogate those responsibilities in the communities of the vulnerable, then the rule of law suffers a staggering, almost unrecoverable blow.

\section{CONCLUSION}

This Article unpacks one key aspect of the rule of law in India. Child marriage in India persists as a national challenge despite the rule of law. For decades, federal law in India has consistently barred underage marriages. Yet, despite numerous laws and aggressive public statements, the rule of law has been ineffective in curbing this socially dominant practice. Further, despite the legal and social challenges associated with child marriage, including severe health effects (such as maternal and child morbidity, venereal diseases, and HIV), domestic violence, malnutrition, and poverty that traps child brides, federal authorities have made limited progress in stopping the practice. Upon inspection, what becomes clear is that custom frequently trumps federal law-often with the complicity or intentional blindness of key governmental actors, such as judges.

As this Article articulates, the rule of law cannot be evaluated in a vacuum isolated from political, cultural, and social contexts. When studied up close, child marriage provides a compelling lens through which to evaluate the effectiveness and capacity of governmental institutions to uphold the rule of law or to make the rule of law meaningful. In isolation, India's rule of law regime regarding child marriage strikes a powerful blow against the exploitation of children. On the ground, however, fundamental weaknesses are revealed, exposing the law's impotence when enforcement mechanisms are lacking. 